\title{
Sodium citrate inhibits proliferation and induces apoptosis of hepatocellular carcinoma cells
}

\author{
Phuc Hong Vo ${ }^{1,2,3}$, Sinh Truong Nguyen ${ }^{1,2,3}$, Nghia Minh Do ${ }^{1,2,3}$, Kiet Dinh Truong ${ }^{4}$, Phuc Van Pham ${ }^{1,2,3,5, *}$
}

${ }^{1}$ Stem Cell Institute, University of Science, Ho Chi Minh City, Viet Nam

${ }^{2}$ Cancer Research Laboratory, University of Science, Ho Chi Minh City, Viet Nam

${ }^{3}$ Viet Nam National University,

University of Science, Ho Chi Minh City, Viet Nam

${ }^{4}$ Medical Genetic Institute, Ho Chi Minh City, Viet Nam

${ }^{5}$ Laboratory of Stem Cell Research and Application, University of Science, Ho Chi Minh City, Viet Nam

\section{Correspondence}

Phuc Van Pham, Stem Cell Institute University of Science, Ho Chi Minh City, Viet Nam

Cancer Research Laboratory, University of Science, Ho Chi Minh City, Viet Nam

Viet Nam National University, University of Science, Ho Chi Minh City, Viet Nam

Laboratory of Stem Cell Research and Application, University of Science, Ho Chi Minh City, Viet Nam

Email:pvphuc@hcmuns.edu.vn; phucpham@sci.edu.vn

History

- Received: 2020-01-05

- Accepted: 2020-03-01

- Published: 2020-03-21

DOI : 10.15419/bmrat.v7i3.592

\section{Check for updates}

\section{Copyright}

( $)$ Biomedpress. This is an openaccess article distributed under the terms of the Creative Commons Attribution 4.0 International license.

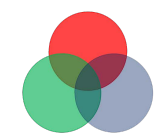

\begin{abstract}
Introduction: Cancer cells rely on glycolysis to generate energy and synthesize biomass for cell growth and proliferation (the Warburg effect). Recent studies have shown that citrate has an inhibitory effect on several cancer cells, such as human gastric cancer and ovarian cancer, by inhibiting glycolysis. In this study, we investigated the effects of citrate on the proliferation and apoptosis induction of hepatocellular carcinoma cells. Methods: HepG2 hepatocellular carcinoma cell line was used in this study. The cell proliferation was evaluated by Alamar blue assay. The apoptotic status of the HepG2 cells was recorded by Annexin V/7-AAD assay and caspase 3/7 activation assay. DNA fragmentation was evaluated by nucleus staining assay with Hoechst 33342 . Results: The results showed that citrate is able to inhibit the proliferation of HepG2 cells and induce apoptosis in these cells. The initiation time of apoptosis is 4 hours after treatment with $10 \mathrm{mM}$ citrate. Morphology characteristics of DNA fragmentation and broken membranes were also recorded in the apoptotic cells. Conclusion: In conclusion, our study demonstrates that citrate causes HepG2 cell death by the apoptosis pathway.
\end{abstract}

Key words: Liver cancer, Apoptosis, Citrate, HepG2, Nuclear fragmentation

\section{INTRODUCTION}

The Warburg effect pathway of cancer cells was reported over 75 years ago by Otto Warburg, and is regarded as a hallmark of cancer cells. Contrary to normal cells, cancer cells metabolize glucose into lactate, although oxygen also exists in this process ${ }^{1}$. Many research studies have focused on this mechanism in order to develop new effective approaches to cancer treatment. Citrate is a precursor to the synthesis of amino acids in cell growth; moreover, citrate can also inhibit glycolysis. By adjusting the important enzymes in advance, during glycolysis (PFK1, PFK2, $\mathrm{PK})$, TCA cycle (PDH, SDH), gluconeogenesis (F1, 6BPase), or amino acid synthesis (ACC), it has been confirmed that citrate is an important intermediary for cell metabolism as well as a key regulator in energy production ${ }^{2}$. When citrate is generated in the TCA cycle, it has reactions that inhibit glycolysis and this cycle, while triggering gluconeogenesis and lipid synthesis.

In 2012, Björn Kruspi et al. concluded regarding the effect of citrate in cancer cells that citrate induces the characteristic manifestations of apoptosis, such as activation of caspase- 3 , cleavage of polymerase polyADP-ribose, and release of cytochrome c. Some other studies have confirmed that citrate can inhibit the proliferation of various cancer cells, such as ovar- ian cancer, leukemia, and medullary thyroid can$\mathrm{cer}^{3-5}$. This study aimed to determine the effects of citrate on the proliferation of HepG2 cell as well as the role of apoptosis induction of citrate on HepG2 cells.

\section{MATERIALS - METHODS}

\section{Citrate}

The $1 \mathrm{M}$ trisodium citrate 2-hydrate solution was made from $2.44 \mathrm{~g}$ of 2-hydrate trisodium citrate powder (Sigma-Aldrich, St. Louis, MO) and $10 \mathrm{~mL}$ of DMEM/F12 medium (Thermo Fisher Scientific, Waltham, MA). The solution was filtered with a 0.2 $\mu \mathrm{m}$ filter and then the sterile solution was kept at 4 ${ }^{\circ} \mathrm{C}$ until further use.

\section{Cell culture}

HepG2 cell line from ATCC (Manassas, VA, USA) was cultured in DMEM/F12 supplemented with $10 \%$ fetal bovine serum (FBS), and $5 \%$ antibiotic-mycotic (Thermo-Fisher Scientific). HepG2 cells were cultured in a $5 \% \mathrm{CO}_{2}$ humidified atmosphere incubator at $37^{\circ} \mathrm{C}$ (Sanyo, Japan).

\section{Cytotoxicity assay}

HepG2 cells were seeded in 96 wells plate (SPL Life Sciences, Korea). The cell density was 2,500 cells per well (in $100 \mu \mathrm{L}$ volume). After $24 \mathrm{~h}$, cells were treated 
with citrate that was serially diluted from $60 \mathrm{mM}$ to $1.5 \mathrm{mM}$. After $48 \mathrm{~h}$ incubation, cells were evaluated for their viability by staining with Alamar Blue and reading the measurements using a multimode reader DTX 880 machine (Beckman Coulter, CA). The experiments were done in triplicate.

\section{Apoptosis assay}

HepG2 cells were seeded in 6 wells plate (SPL Life Sciences, Korea). The cell density was 200,000 cells per well (in $1000 \mu \mathrm{L}$ volume). The cells treated with 10 $\mathrm{mM}, 15 \mathrm{mM}, 20 \mathrm{mM}$ or $25 \mathrm{mM}$ citrate and incubated for $48 \mathrm{~h}$. Cells were labeled with $3 \mu \mathrm{L}$ Annexin VFITC (BD Biosciences, Franklin Lakes, NJ) (and $3 \mu \mathrm{l}$ of Propidium Iodide (PI) in $500 \mu \mathrm{L}$ of binding buffer for $15 \mathrm{~min}$ to detect apoptotic and necrotic cell death. The apoptotic cells were detected using a FACSCalibur flow cytometer. Data were analyzed by CellQuest Pro software (BD Biosciences, Franklin Lakes, NJ). The experiments were done in triplicate.

\section{C aspase 3/7 activation assay}

HepG2 cells were labeled with CellEvent Caspase3/7 Green Detection Reagent (Thermo Fisher Scientific, Waltham, MA) and incubated for $30 \mathrm{~min}$ in a 5 $\% \mathrm{CO}_{2}$ humidified atmosphere at $37^{\circ} \mathrm{C}$. Cells were captured by a Zeiss Axio Imager fluorescence microscope, at FITC filter and white light, with the timelines of $30 \mathrm{~min}, 2 \mathrm{~h}, 4 \mathrm{~h}$, and $6 \mathrm{~h}$, using the $10 \mathrm{X}$ objective. CellEvent Caspase-3/7 Green Detection Reagent is a four amino acid peptide (DEVD) associated with DNA fluorescent dye recognized by caspase $3 / 7$. This substrate did not initially fluoresce by DEVD-based dye inhibition. The reagent traveled through the cell membrane to enter the cytoplasm. When apoptosis occurs, the DEVD peptide is separated, allowing the dye to bind to DNA and produce a fluorescent substance. This allows 3/7 caspase activity to be monitored in intact cells immediately ${ }^{6}$. The experimental study was conducted in triplicate.

\section{Nuclei staining assay}

HepG2 cells were treated with $15 \mathrm{mM}$ citrate for 48 hours. They were then mixed with $100 \mathrm{~mL}$ Hoechst 33342 dye (Abcam, UK) and incubated for $10 \mathrm{~min}$. The dyed cells were observed under the microscope (Zeiss, Germany) at fluorescence objective $50 \mathrm{X}$ and $100 \mathrm{X}$.

\section{Statistical analysis}

The data from the cytotoxicity assay was calculated to derive the $\mathrm{IC}_{50}$ value. This experiment was repeated three times and processed statistically with $95 \%$ confidence intervals. The data were processed statistically by GraphPad Prism 7 software (GraphPad Software, La Jolla, CA).

\section{RESULTS}

\section{Citrate inhibited the proliferation of HepG2 cells}

The resulting half-cell inhibitory concentration $\left(\mathrm{IC}_{50}\right)$ shown in Figure 1 showed that the survival rate of HepG2 cells decreased with response to citrate concentration. The average $\mathrm{IC}_{50}$ value was $12.650 \pm 0.115$ $\mathrm{mM}$. According to Figure 2, at a citrate concentration of $60 \mathrm{mM}$, most HepG2 cells change in morphology. They shrink, float, and form round cells. In our study, at $15 \mathrm{mM}$ citrate, the percentage of cells with normal morphology and changed morphology was equivalent. For citrate at the concentration of $1.5 \mathrm{mM}$, there were few HepG2 cells in the circular form (most of the cells still clung firmly).

\section{HepG2 cells displayed the apoptosis phe-} notype after treatment with citrate

HepG2 cells were treated with citrate at the concentrations of $10 \mathrm{mM}, 15 \mathrm{mM}, 20 \mathrm{mM}$, and $25 \mathrm{mM}$, respectively, for 48 hours. The percentage of apoptotic cells is shown in Figure 3. After 48 hours of treatment with $10 \mathrm{mM}$ citrate, $6.47 \%$ of cells were undergoing apoptosis and $2.24 \%$ were late apoptosis or necrosis. When treated with $15 \mathrm{mM}$ citrate, the percentage of cells with late apoptosis or necrosis (and early apoptosis) decreased trivially, compared to the concentration of $10 \mathrm{mM}$. This ratio was respectively $1.66 \%$ to $5.51 \%$. This rate increased to $10.46 \%$ of cells with early apoptosis, or $4.24 \%$ of cells with late apoptosis or necrosis when treating HepG2 with citrate 20 $\mathrm{mM}$. At the highest concentration of citrate $(25 \mathrm{mM})$, the percentage of living cells is only $50.08 \%$. Remarkably, the rate of cells with late apoptosis/necrosis increased dramatically to $7.63 \%$, nearly 7 times higher than the control cells. The proportion of early apoptosis cells also accounted for the highest proportion in the treated samples (12.19\%).

\section{The start time of the apoptosis signal was after $\mathbf{4} \mathrm{h}$ of treatment with citrate}

HepG2 cells were treated with citrate $(10 \mathrm{mM})$ and monitored for time-lapse using the 10X objective with a fluorescent microscope to identify the time that treated cells began exhibiting the apoptosis phenotype. At the 30-minute mark after treatment, there was no signal of apoptosis- treated cells with $10 \mathrm{mM}$ 


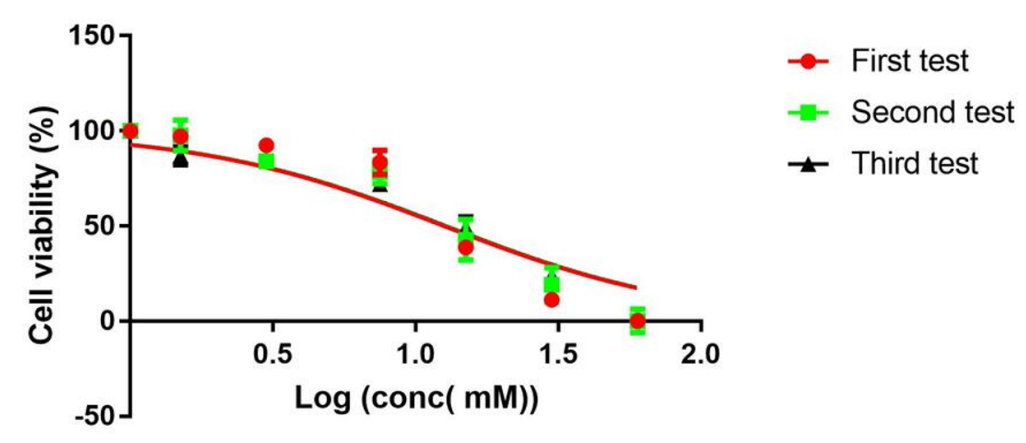

Figure 1: IC 50 when treating citrate on HepG2 cells. The average absorbance was detected by the Alamar blue method after 48 hours of HepG2 treatment with a citrate in 2 folds dilution concentration range from $60 \mathrm{mM}$ to 1.5 $\mathrm{mM}$ at $535 \mathrm{~nm}$ and measuring the emission at $620 \mathrm{~nm}$. Data were processed using Graphpad Prism 7 software.

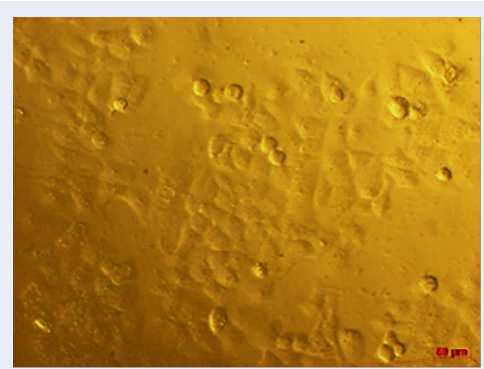

Control

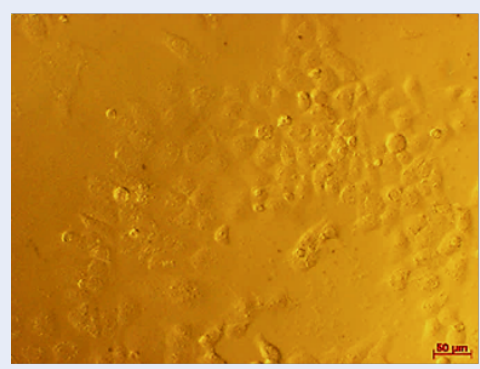

Citrate $15 \mathrm{mM}$

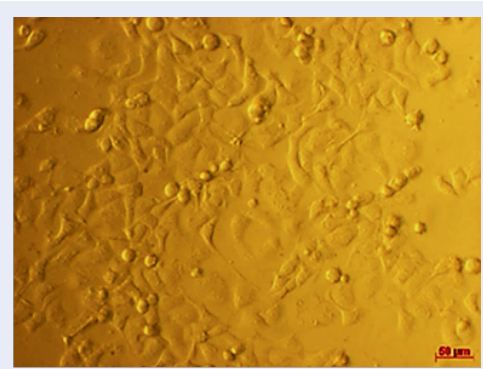

Citrate $1.5 \mathrm{mM}$

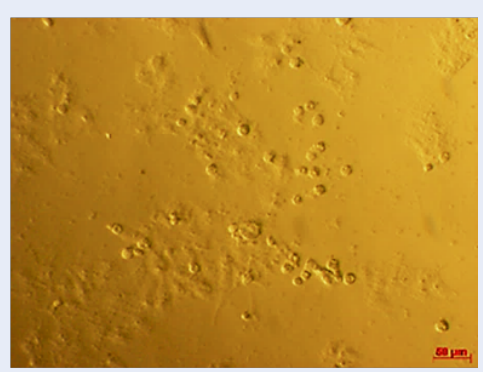

Citrate $60 \mathrm{mM}$

Figure 2: Morphology of HepG2 cells after treatment with citrate at $1.5 \mathrm{mM}, 15 \mathrm{mM}, 60 \mathrm{mM}$ citrate and controls. HepG2 cells were recorded by microscope image (20X magnification) after 48 hours of treatment with citrate at concentrations of $1.5 \mathrm{mM}, 15 \mathrm{mM}$ and $60 \mathrm{mM}$ and control samples, respectively. Cell density 2,500 cells/well. Cell morphology varies depending on the concentration of citrate treated. 


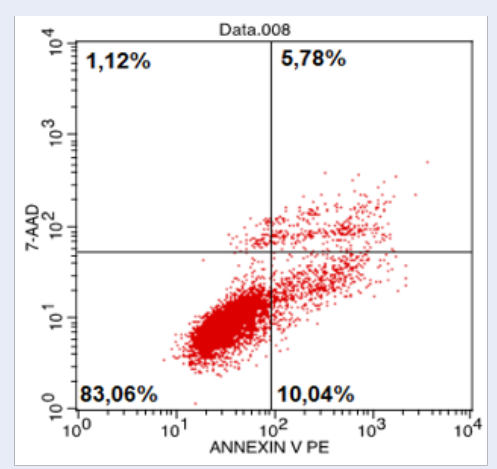

\section{Control}

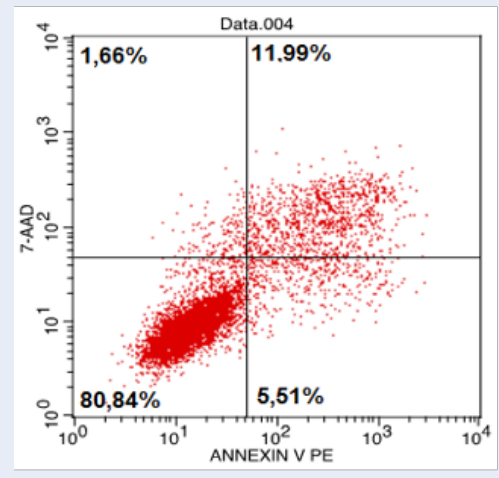

Citrate $15 \mathrm{mM}$

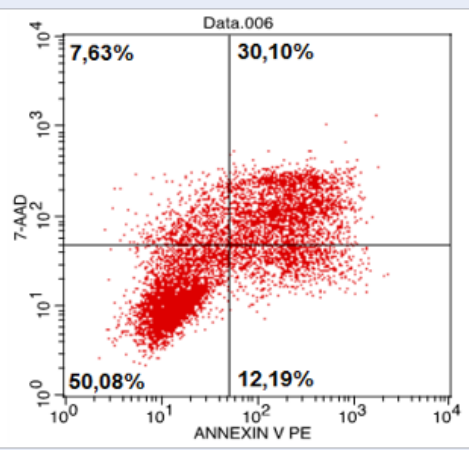

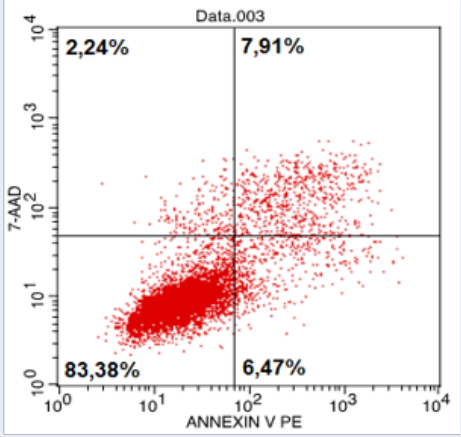

\section{Citrate $10 \mathrm{mM}$}

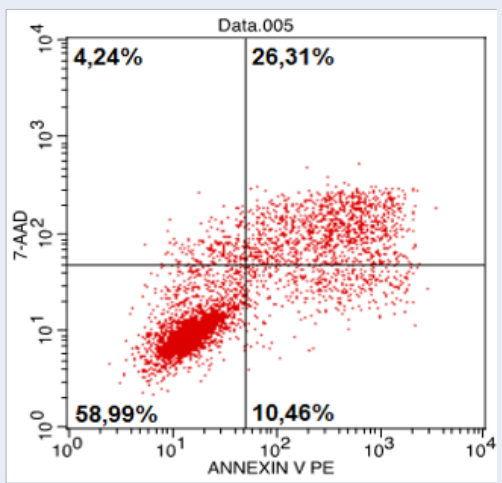

Citrate 20mM

\section{Citrate $25 \mathrm{mM}$}

Figure 3: Results of apoptosis analysis of HepG2 cells when treated with $10 \mathrm{mM}, 15 \mathrm{mM}, 20 \mathrm{mM}, 25 \mathrm{mM}$ citrate and control. HepG2 cells were treated with citrate in concentrations of $10 \mathrm{mM}, 15 \mathrm{mM}, 20 \mathrm{mM}, 25 \mathrm{mM}$ and control samples for 48 hours, respectively. The cells were stained with AnnexinV-PE/7-AAD. Identify cell signals using FACS calibur. 


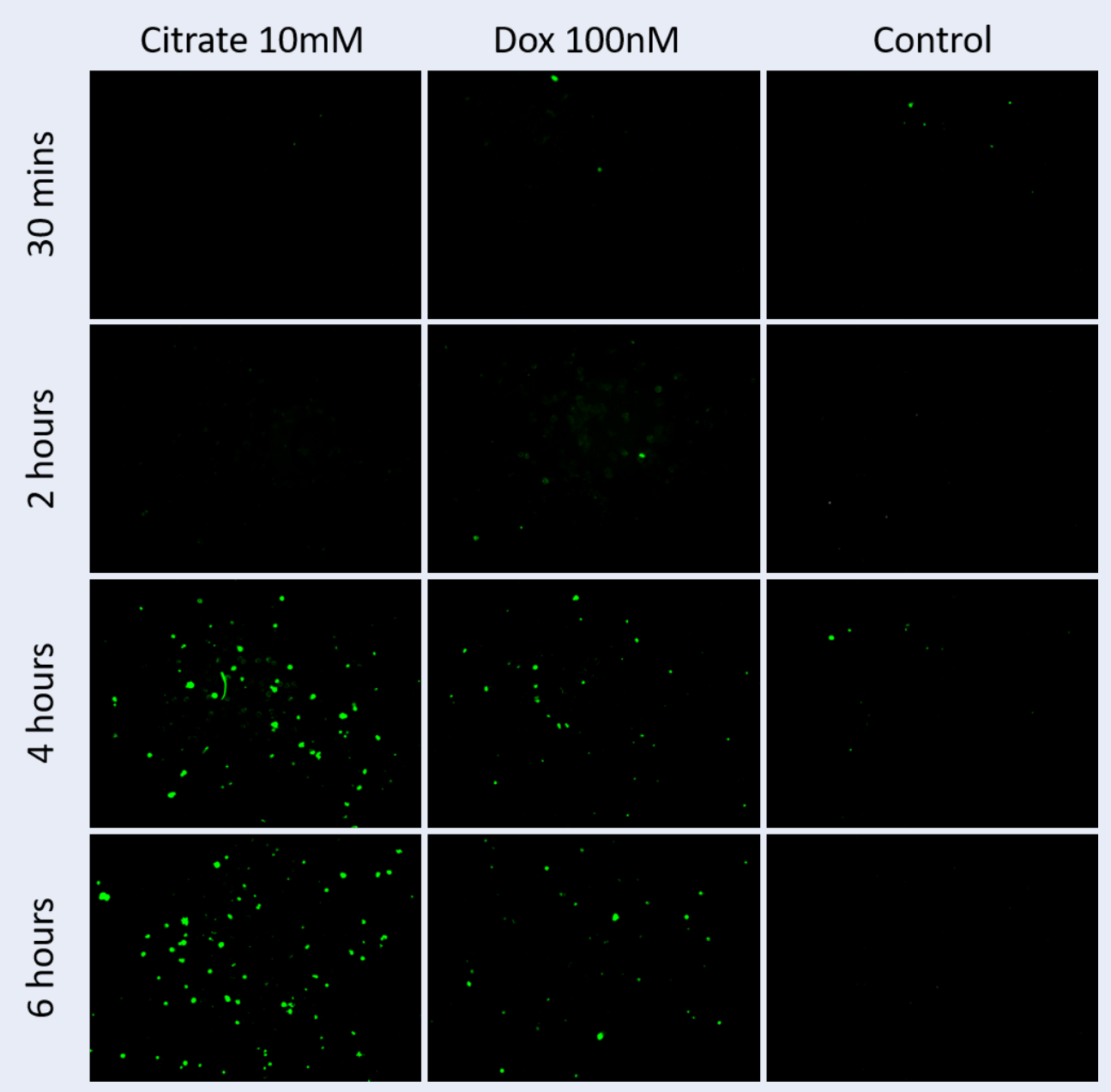

Figure 4: Caspase-3 activity on HepG2 cells treated with $10 \mathrm{mM}$ sodium citrate. HepG2 cells were cultured in a 6-well plate, with a density of 200,000 cells/well. Test sample: HepG2 cells treated with citrate $10 \mathrm{mM}$. Positive control: HepG2 cell treated with doxorubicin $100 \mathrm{nM}$. Control sample used cell culture medium. All cell samples were stained with CellEvent Caspase-3/7 Green Detection Reagent $5 \mu \mathrm{M}$ and recorded by fluorescence microscope (10X magnification) for 30 minutes, 2 hours, 4 hours and 6 hours. Apoptosis cells emit green fluorescence under a fluorescent filter.

citrate. Similarly, after 2 hours, apoptosis had not even occurred in these cells. However, the signal of apoptosis started to be observed at $4 \mathrm{~h}$ (Figure 4). The treated cells with citrate showed bright, clear and bright green fluorescence signals. The number of apoptotic cells increased sharply compared to previous time points as well as compared to the two control samples. Positive controls (treated with doxorubicin) showed more apoptotic cells than the 2-hour mark but the incidence did not increase as much as the citrate treatment (Figure 4). Most HepG2 cells in negative control groups do not have any signal/signs of apoptosis, and only a few have fluorescence signal but are still eligible. This proves that the apoptosis recorded by the cell is due to effect of $10 \mathrm{mM}$ citrate and 100 nM doxorubicin on the cell. The manipulation process does not affect the cause of apoptosis for the cell. At the 6-hour mark, cells treated with $10 \mathrm{mM}$ citrate continued to increase the signal of apoptosis but the rate of growth was not as high as before. Cell samples treated with doxorubicin at $100 \mathrm{nM}$ (positive control) and negative control samples still displayed similarly to the 4-hour period.

In addition, HepG 2 cells after 6 hours treatment with citrate were observed under the inverted fluorescence microscopy with fluorescent filters and white light to better visualize the morphology of apoptosis cells. According to the results from Figure 5, at $10 \mathrm{mM}$ citrate, 


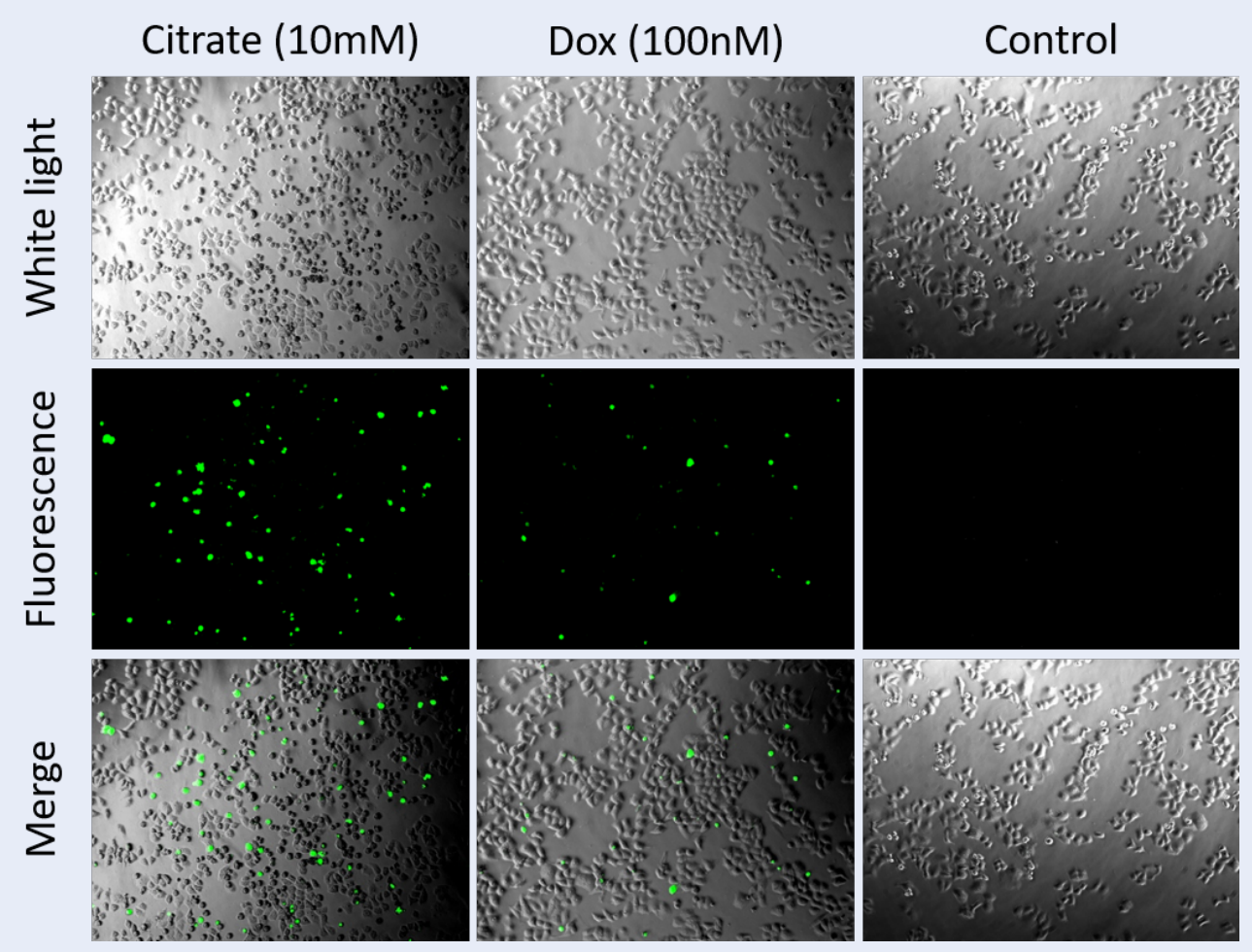

Figure 5: Caspase-3 activity on HepG2 cells was treated with $10 \mathrm{mM}$ sodium citrate after $\mathbf{6}$ hours. HepG2 cells were cultured in a 6 -well plate with a density of 200,000 cells/well. HepG2 cells were treated with $10 \mathrm{mM}$ citrate, doxorubicin $100 \mathrm{nM}$ and control. All samples were stained with CellEvent Caspase-3/7 Green Detection Reagent $5 \mu \mathrm{M}$ and recorded with fluorescence filter, white light in the same point with fluorescence microscope (10X magnification) after 6 hours incubation. The merging image shows more clearly apoptosis cells underwhite light. Apoptosis cells emit green fluorescence under a fluorescent filter.

the cells are transformed into round cells, accounting for about half the cell density. These round cells are mostly in the process of apoptosis. With a concentration of $100 \mathrm{nM}$ of doxorubicin, the round cells induced apoptosis when combined with fluorescent light. The control sample consisted of round cells, but no fluorescence signal appeared so the cells did not die by apoptosis but could be caused by other pathways.

\section{Nuclear fragmentation was detected when HepG2 cells were treated with citrate}

Under the fluorescent light, apoptotic cells emit green fluorescence, the nucleus divides into fragments, and there is formation of individual clusters that can be clear and bright when seen with $100 \mathrm{X}$ objective (Figure 6) .

\section{DISCUSSION}

Following a different metabolic pathway, cancer cells tend to break down most of the glucose they get into lactate $(85 \%)$ and maintain the glycolysis process regardless of the presence of $\mathrm{O}_{2}$; this is called the Warburg pathway effect ${ }^{1}$. Understanding these characteristics of cancer cells can open the door to researching direct effects on glycolysis by potential factors, such as 3-bromopyruvate, lonidamine, 2deoxyglucose $^{7}$, and especially citrate. In life, citrate exists naturally in citrus fruits, such as oranges, lemons, and grapefruits ${ }^{8}$. In addition, sodium citrate is a compound used in foods mainly as a food additive. It is often a flavoring agent used in many types of carbonated water or preservatives. In cells, citrate is not only one of the important intermediates in cell metabolism but also a potential factor in inhibiting tumor growth ${ }^{2}$. Citrates strongly inhibit glycolysis by blocking the first PFK enzyme of glycolysis. In parallel, citrate activates new glycogen synthesis ${ }^{9,10}$. In this study, we showed that citrate can inhibit hepatocellular carcinoma cell proliferation by inducing apoptosis in those cells. 

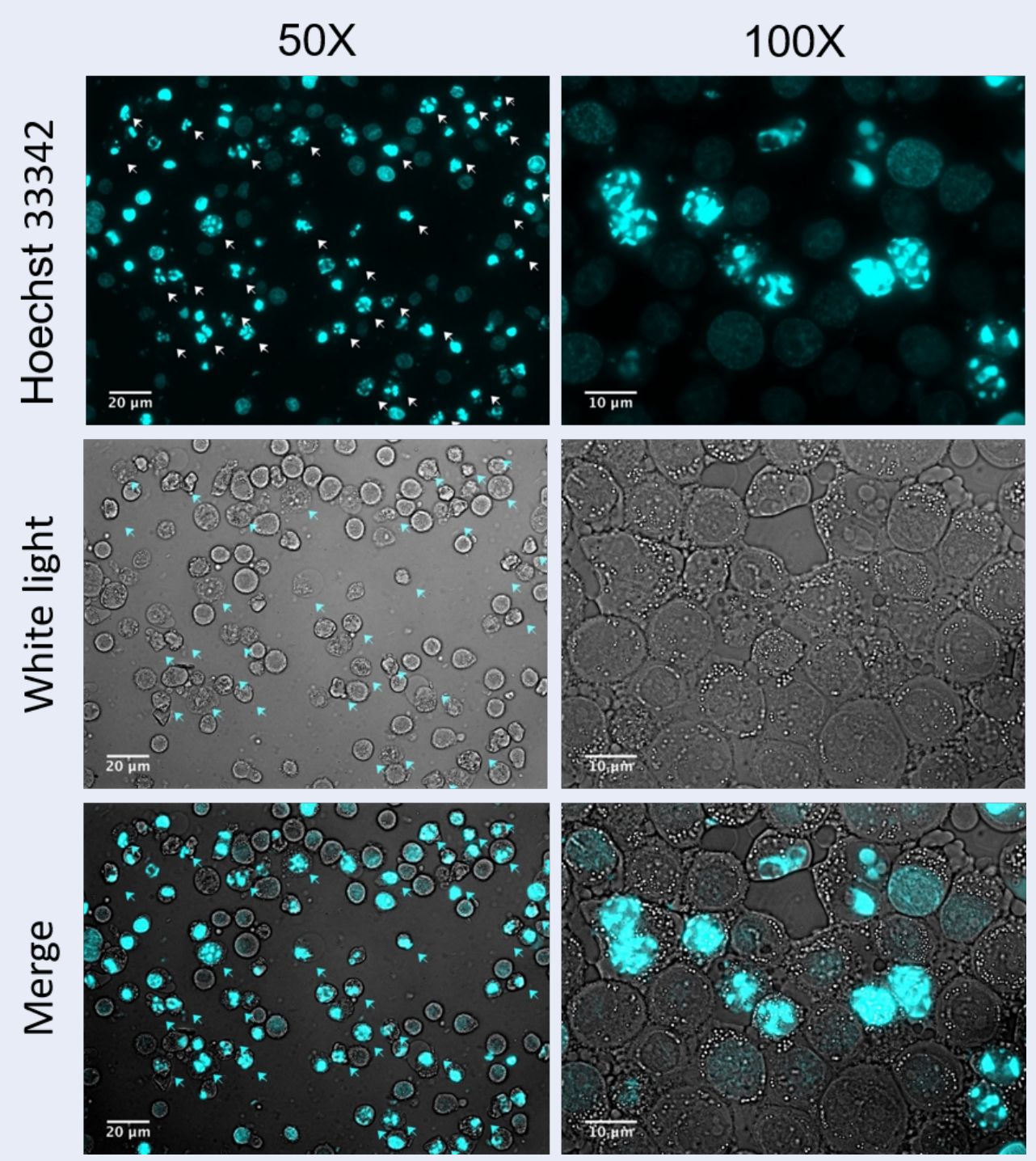

Figure 6: Nuclear fragmentation of HepG2 cells. HepG2 cells after treatment with $15 \mathrm{mM}$ citrate $24 \mathrm{~h}$ were isolated, stained Hoechst 33342, spread on lame and observed under 50X, 100X magnification fluorescence microscope. The image was recorded with fluorescent filters and white light in the same point.

Indeed, HepG2 cells were treated with citrate at various concentrations- from $60 \mathrm{mM}$ to $1.5 \mathrm{mM}$ in 48 h. The $\mathrm{IC}_{50}$ result of citrate was $12.650 \pm 0.115 \mathrm{mM}$. Compared with the results of Xingyu Guo, Xiaodong Zhang et al. (2016), who researched the effects of citrate on MGC-803 stomach cancer cell lines in 48 hours, the $\mathrm{IC}_{50}$ value was $10.08 \pm 0.87 \mathrm{mM}^{11}$. The $\mathrm{IC}_{50}$ of citrate on HepG2 line in our study was found to be 1.25 -fold higher than that of stomach cancer cells ${ }^{11}$.

To confirm the effects of citrate on HepG2 proliferation through activation of apoptosis, we evaluated the phenotype of apoptotic cells via the expression of
Annexin-V. The results confirmed that citrate successfully induced apoptosis of HepG2 cells. Similarly, in previous studies, citrate was also known as an apoptosis inducer in some cancer cell lines, such as MGC$803^{11}, \mathrm{BGC}-823$ and SGC-790 ${ }^{12}$. In other experiments, we also showed that citrate could activate caspase $3 / 7$ after $4 \mathrm{~h}$ of treatment at $\mathrm{IC}_{50}$ dose. In the last experiment, nuclear defragmentation was recorded in cells treated with citrate at $\mathrm{IC}_{50}$ dose. 


\section{CONCLUSION}

This study shows that citrate could inhibit the cell proliferation of hepatocellular carcinoma cells HepG2. The cells treated with citrate completely displayed the apoptosis phenotype, such as expression of Annexin $\mathrm{V}$, activation of caspase $3 / 7$, and defragmented nuclei. This study opens up research possibilities for applying these observations to understanding the full potential and use of citrate in cancer treatment.

\section{ABBREVIATIONS}

7-AAD: 7-Aminoactinomycyna D

ACC: Acetyl-CoA carboxylase

ADP: Adenosine diphosphate

DNA: Deoxyribonucleic acid

F1,6BPase: Fructose 1,6-bisphosphatase

IC $_{50}$ : Inhibitory concentration $50 \%$

PDH: Pyruvate dehydrogenase

PFK1: Phosphofructokinase

PK: Pyruvate kinase

SDH: Succinate dehydrogenase

TCA: Tricarboxylic acid

\section{CONFLICT OF INTERESTS}

The authors report no conflicts of interest in this work.

\section{ACKNOWLEDGMENTS}

This work was supported by the Vietnam National University, Ho Chi Minh City, Vietnam, under grant A2015-18-01.

\section{AUTHOR'S CONTRIBUTION}

PHV, STN, NMD performed the experiments, analyzed data and drafted the manuscript. KDT, PVP suggested the idea, explained the data, corrected the manuscript. All authors approved the final manuscript.

\section{REFERENCES}

1. Warburg O. On the origin of cancer cells. Science . 1956;123(3191):309-314. PMID: 13298683. Available from: https://doi.org/10.1126/science.123.3191.309.

2. Icard P, Poulain L, Lincet $H$. Understanding the central role of citrate in the metabolism of cancer cells. Biochimica et Biophysica Acta (BBA)-Reviews on Cancer. 2012;1825(1):111116. PMID: 22101401. Available from: https://doi.org/10.1016/ j.bbcan.2011.10.007.

3. Bucay AH. Hypothesis proved... citric acid (citrate) does improve cancer: a case of a patient suffering from medullary thyroid cancer. Medical hypotheses. 2009;73(2):271. PMID: 19409713. Available from: https://doi.org/10.1016/j.mehy. 2009.03.018.

4. Kruspig B, Nilchian A, Orrenius S, Zhivotovsky B, Gogvadze V. Citrate kills tumor cells through activation of apical caspases. Cellular and molecular life sciences. 2012;69(24):42294237. PMID: 23052210. Available from: https://doi.org/10. 1007/s00018-012-1166-3.

5. Lincet $H$, Kafara $P$, Giffard $F$, Abeilard-Lemoisson $E$, Duval $M$, Louis $\mathrm{MH}$, et al. Inhibition of $\mathrm{Mcl}-1$ expression by citrate enhances the effect of $\mathrm{BCl}-\mathrm{x} \mathrm{L}$ inhibitors on human ovarian carcinoma cells. Journal of ovarian research. 2013;6(1):72. PMID: 24103422. Available from: https://doi.org/10.1186/1757-22156-72.

6. Salvesen GS. Caspases and apoptosis. Essays In Biochemistry. 2002;38:9. PMID: 12463158. Available from: https://doi.org/ 10.1042/bse0380009.

7. López-Lázaro M. The warburg effect: why and how do cancer cells activate glycolysis in the presence of oxygen? Anti-Cancer Agents in Medicinal Chemistry (Formerly Current Medicinal Chemistry-Anti-Cancer Agents). 2008;8(3):305-312. PMID: 18393789. Available from: https://doi.org/10.2174/ 187152008783961932.

8. Haleblian GE, Leitao VA, Pierre SA, Robinson MR, Albala DM, Ribeiro AA, et al. Assessment of citrate concentrations in citrus fruit-based juices and beverages: implications for management of hypocitraturic nephrolithiasis . Journal of endourology. 2008;22(6):1359-1366. PMID: 18578663. Available from: https://doi.org/10.1089/end.2008.0069.

9. Berg JM, Tymoczko JL, Stryer L. Biochemistry; W. H. New York: Freeman and Company: New York. 2002;.

10. Schwinger A. The Molecular Basis of Cell Structure and Function. World Publ, New York. 1970;.

11. Guo X, Zhang X, Wang T, Xian S, Lu Y. 3-Bromopyruvate and sodium citrate induce apoptosis in human gastric cancer cell line MGC-803 by inhibiting glycolysis and promoting mitochondria-regulated apoptosis pathway. Biochemical and biophysical research communications . 2016;475(1):3743. PMID: 27163639. Available from: https://doi.org/10.1016/j. bbrc.2016.04.151.

12. Lu Y, Zhang $X$, Zhang H, Lan J, Huang G, Varin E, et al. Citrate induces apoptotic cell death: a promising way to treat gastric carcinoma? Anticancer research. 2011;31(3):797-805. 